
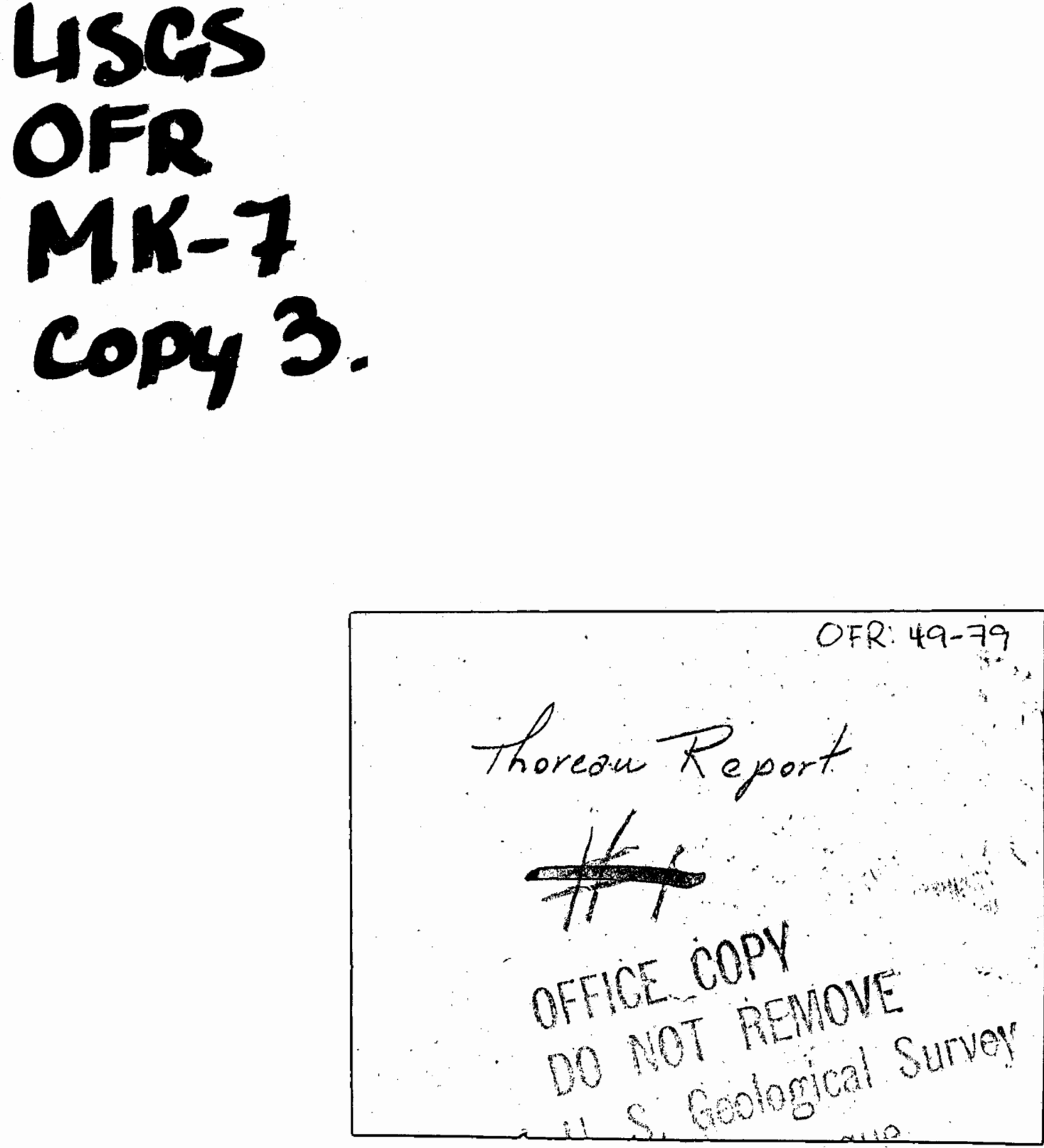

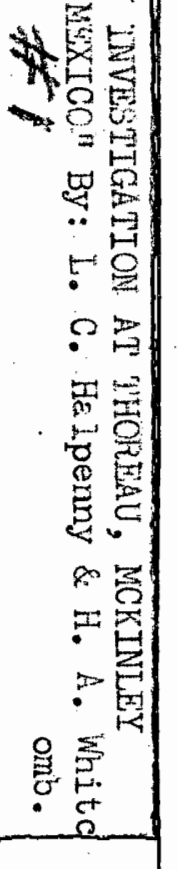

15. GEOLOGICA SURVE

WRD, LBRARY MUETTE NW, RM 70

SO5 MA? QUERE, N.M 37102






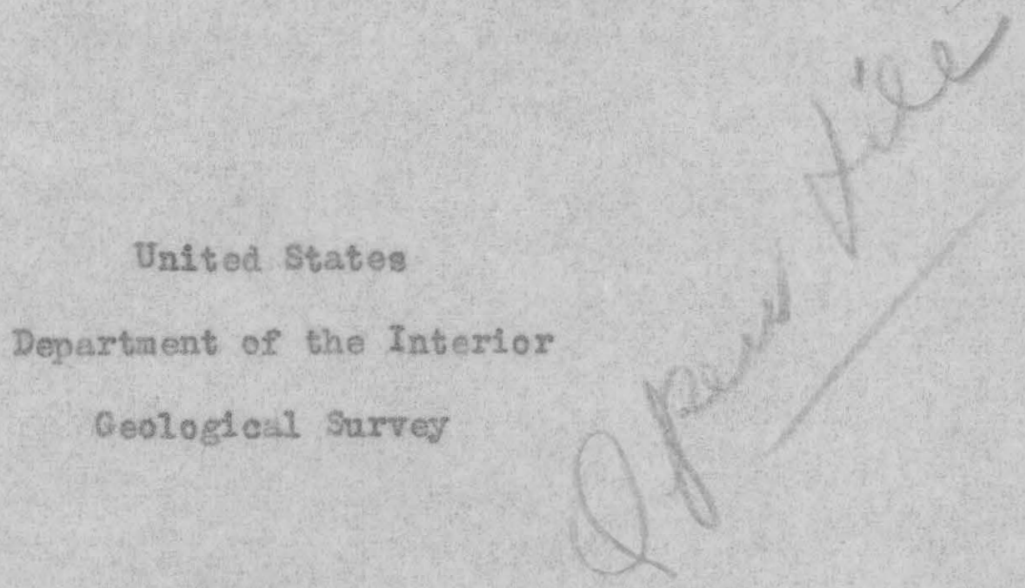

US. GEOLOGICAL SURVET WRD, LIBRARY 505 MARQUETTE NW,
ALBUQUERQUE, N.M. 87102

\author{
Nater-sappiy investigation at Thoreau, \\ HeKinley Gounty. New Mexico \\ $\mathrm{By}$
}

I. C. Halpenny and H. A, Thiteomb

OFFICE COPY

DO NOT REMOVE

U. S. Goological Survay GW-Albuquerque

Albuqueroue, Men Mexico

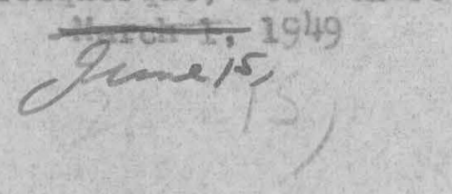




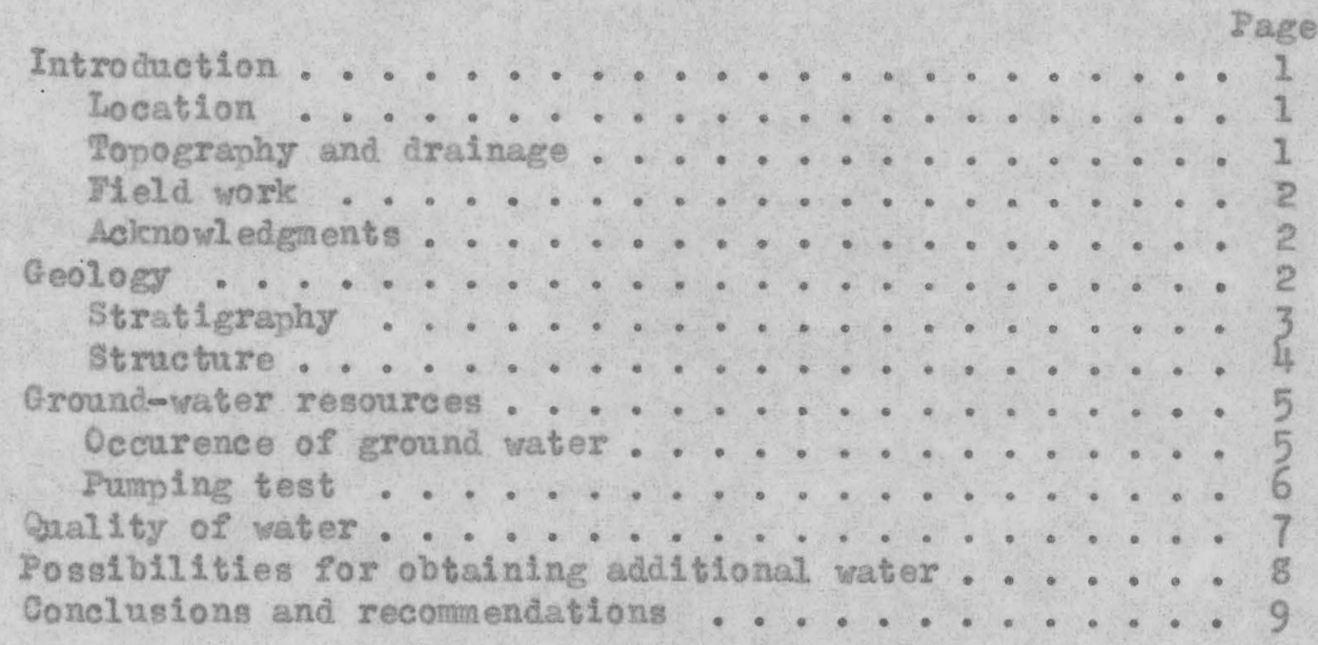

\section{TABI, THS}

1. Records of wells and springs in Thorear area, MeKinl ey County, New Mexico ............ 10

2. Logs of wells in Thoreau area, MeKinley County, New Mexlco................... 12

3. Analyses of water fron vells and springs in Thoreau area, McKinley County, New Mexico ........ 15

\section{ILIUSWRATIONS}

Plate 1. Map of part of Mokinley County, Ifew Mexico, showing locations of vells and springs in vicinity of Thorean and Prewitt. 


\section{INTRO DUCP ION}

The Indian school at Thoreau, Mekinl ey County, New Mexico, has been closed for several years. When the school was in operation, water was supplied from a well which produced from sandstone in the Chinle formation. The pump was removed and the vell was capped at the time that the schonl was closed. In 1948 the Navajo Service desired to reopen the school. The Geologleal Survey had been studying ground-water problens on the Havajo Indian Reservation sinee Jamary 1948, and the Navajo Service requested that the progran include Indian schools, such as the one at Thoreau, that are not on the Reservation, but are, nevertheless, the responsibility of that office. Accordingly, the Geologieal Survey made a brief reconnalsance to determine the adequacy of the existing water supply at Thorean and to make recommendations for further development if necessary.

It was reported that about 20,000 gallons of water per day would be needed for operation of the school on a boarding basis. A continuous discharge of 14 gallons per minute would be needed to furnish this anount of water. Pumping 16 hours per day, about 21 gallons per minute would be required.

\section{Location}

Thoreau is located in south-central MeKinley County. Mev Mexico, about 4 miles east of the Continental Divide and 35 miles east of Gallup. U. S. Highway 66 and the Santa Fe Rall road pass through the settlement. State Highway 56, a graded road, links Thoresu with Crown Point, 37 miles to the

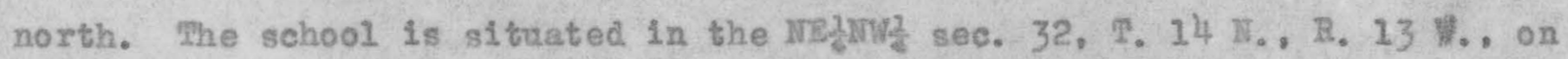
40 acres of land allotted to the Navajo Service by the Federal Government.

\section{Topography and drainage}

Thoreau lies on the north flank of the Zuni uplift. Topographically. 
the region may be described generally as characteristic of a dissected dome. A series of cuesta ridges of sandstone parallel the axis of the dome, with steep escapfment slopes facing southward in the direction of its center, Broad, flat vallegs cut in beds of shale lie between the cuesta ridges and facilitate travel from east and west across the uplifted area.

Drainage is predominantly to the east, away from the Continental Divide which attalns an altitude of 7.246 reet 4 miles vest of Thorean. The altitude at Thoreau is about 7,150 feet. The land surface siones so gently to the east that strean gradients are too low to accomplish much dow cutting.

\section{Pleld work}

A purming test was made by L. C. Halpenny, engineer, H. A. Whitcomb, geologist, and A. D. Pulido and G. A. Lerua, student engineers, during the period dagust 17-20, 1948. Records of shallow wells and vater samples were collected by H. A. Whitcomb and R. J. Drake in early December 1948.

Acknovl edgments

J. D. Hem, Distriet Chemist, Quarity of Vater Branch, prepared the quallty-of-water section for this report. C. V. Theis, Distriet Geologist for ground-water investigations in Mew Mexico, gave helpful suggestions during the course of the investigation and revieved the report. H. B. Skibitzke, engineer, reviewed the computations for the prinping tegt. C. B. Read, Geologist, Thels Section, Geologie Division, discussed the stratigraphy of the region with the anthors and reviewed the geologie section of the report.

\section{GROLOGY}

The broad, flat valley in wich the torm of Thoreau is situated is underlain by Mriassic and Permian strata. The lowest stratigraphic unit which eould be considered as a possible aquifer at Thorean is the olorieta sandstone menber of the Middle Pernian Sen Andres formation. The rocks below this nember are known to yield water of poor quality in the region, and therefore they will not be discussed in this report. The geologic section was exanined in the vieinity of Prewtt, 10 miles east of Thorean, where 
better exposures occur. The thicknesses in that vicinity are considered to be applicable to the strata in the Thoreau area.

\section{Stratingaphy}

The Glorieta sandstone member of the Niddle Pemian San Andres formation Is not exposed in the aree studied. The $10 \mathrm{~g}$ of well 9 (table 2) Indicates that the menber is about 188 feet thick in the Vlelnity of Prewitt. Finosures in other narts of the region show that the Glorleta sandstone nember is gray, finegrained, hard, nassive, and eross bedded.

The San Andree 1 inestone menber of the San Andres formation is the youngest of the Pernlan strata exposed in the area. About 250 feet of this gray, coarsegrained, nassive, sandy 11 mestone, contatuing abundant Middie Pemalan fos sils, crops out in the wall of 3luewatex Ganyon about 6 miles southwest of thorean. The contact with the underlying Gloriata sandstone menber was not observed in the area exanined.

Tmediately overlying the San Andres fornation is about 30 feet of red, medivn-grained, rather soft, shaly to thin-bedded sandstone which contaias scattered. small quartgite pebbles. According to Read, $\mathcal{H}$ this sandstone may be the equivaleat of the Shinammp conglomerate, of Upper (?) Trlassic age.

Overlying the Shinasuarp (f) conglonerate is an estimated thickness of 260 feet of soft red, gray, and purplish ehale, contasning beds of generally coarse and comoniy cross bedded gray sandstone. These deposits were designated by Darton ${ }^{2 /}$ as the Moenkopi formation. Recont studies by $\sigma .3$. Read, in a paper by Theis $3 /$, produced paleobotanical evidenee that these beds are of a later Triagsic age than Moenkopl, and suggest that they are nore properly correlated with the chinle formation than with the much older Moenkopi foxaation. These beds are designated in this report

I/ Read, O. B., Oral commuleation, Decomber 10, 1948.

2f Darton, M. H., "Red Beds" and assoclated fometioas in Men Mexico: T. S. Geol. Survey Bar1. 794, p. 143, 1928.

3) Theis, C. $\nabla_{0}$, Ground-water conditions near Mingate Ordnance Depot: U. S. Geol. Survey (Report to Army Pingineers), pp. 10-11, 1941. 
as the "lower shale member of the Chinle formation".

About 100 feet of gray to buff, coarse-gralned, rather hard, massive sandstone containing conglomeratic lenges in its lower part, overlies the lower shale menber of the Chinle fomation. Whis sandstone is exposed at the top of the steep south-facing escarpwent slope south of Thoreau. This sandstone was correlated with the Shinaruap conglomerate by Darton. 4/ In this report it is designated as the "middle saridstone menber of the Chinle formation".

Confornably overlying the aldele sandatone member of the Chinle fomation Is about 1,200 feet of soft gray, naroon, and purple shales and Interbedded thin red to brown sandstones. This sequence is designated in this report as the "upper shale member of the Chinle formation". Trosion of these beds has produced the wide valley lying between the sandstone-eapped cuesta to the south and the red sandstones of Jurassie age which form the high ellffs of Dutton Plateav to the north.

\section{Structure}

The Zuni uplift consists of an elongated dome, the axis of which strikes roughly northwest. The strata on the northeastern flank dip aniformly to the north and northeast at angles ranging from $2^{\circ}$ to $3^{\circ}$. Dips are much steeper on the southwestern flank. The northeastern 1 imb of the upwarp has been dissected by erosion to form a series of northwest-trending cuestas. The areas between successive cuestas are occupled by broad valleys cut into soft Trlassic. Jurassic, and Cretaceous shales lying between more rasistant sandstones and 1imestones.

The only fault observed in the area is evident in the southern wall of Drtton Plateau, about 5 miles northeast of Thoreau. Darton's/ geologic map of the Zuni Mountain region shows this fault as probably extending from the south rim of the plateau southward about 25 miles to the core of the zuni uplift. The east side is upthrown.

4/ Darton, N. H., op. cit... p. 143. 5/ Darton, I. H., op. eit., pl. 33. 


\section{GROUND-VARER RESOURCSS}

It is not believed advisable to consider the strata below the San Andres formation as a source of ground water for the thoreau school, as the quality of vater yielded by these strata is known to be poor. The discusaion of ground-water resources is confined, therefore, to the water-bearling character of the rocks described in the geologic section of this report.

\section{Occurrence of ground vater}

The Glorleta sandstone member of the San Aadres formation ylelds water to three railrosd wells at Chavez (pl. 1). Two of the wells flov, and in the third well the vater level is reported to be about 10 feet below the land surface. The altitude at Thoreau is about 100 feet higher than at the wells, and therefore a vell at Thoreau that taps the member could not be expected. to 110\%. The top of the member is estinated to be about 850 feet below the 1.end surface at Thoreau.

The San Andres limestone ramber of the San Andres fortation is not know to be water bearing in the area. However, it is possible that soue of the water produced from the wells at Chavez is obtained from the San Andres 1 imestone member.

It is reported that the Shinarump $(?)$ conglomerate does not jield water to the rail road welis at Chaver. The top of the fomation is estimated to be about 650 feet below the 1 and surface at the school, but an exantnation of the outcrops Indicated that the fomation may not transait wrater readily.

The lower shale nember of the Chinle formation is not water bearing in the area. The aidale sandstone member is believed to be the principai aquifer In the school well (see log, well 19, table 2). The $10 \mathrm{~g}$ shows that 20 feet of water-bearing sand. was encountered at 343 feet. The sandstone beds of the 
upper shale rember yield small amounts of water to domestic wells in the area. Wells 21 and 22 (table I) are reported to produce water from a depth of about 200 ieet.

\section{Pamoing test}

In oxder to determine if the school vell at Thoreau would supply $y_{A}$. gallons per minute, a pumping test was rade in lagust 1948. During the test, water samples were collected for analysis. Priox to the test the well had been capped for at least 6 years. The well was pumped by air lift during the test, and the average discharge was 13.8 gallons per minute for 5 hours and 52 minutes. The well is 1 ined with 10 -inch casing, perforated from about 340 to 365 feet. Although there were four vells within a radius of a mile from the school well, they did not produce water from the middle sandstone mesber of the Chinie fomation.

The trangissibility of the aquifer was calculated by the Fhei $6 /$ method, according to the following equation:

$$
=264 q \frac{10 \Omega t / t^{\prime}}{s}
$$

In which $\%=$ coefficient of transmissibllity, expressed in field terng as the mumber of gallons of water per day that percolates under prevaliling conditions through each aile of water-bearing bed under investigation (messured at right angles to the direction of flow) for each foot per mile of hydraulic gradient

$q=$ discharge of the pumped well, in gallons per mimte

$t=t i m e$ since pumping began, in hours

$t^{\prime}=$ time since pumping stopped, in hours

$s=$ residual dravdown, in feet.

6f Theis, $0.7 .$. The relation between the lowering of the plezonetric surface and the rate and duration of discharge of a well using ground-water storage: Aal. Geophys. Union Trens., 1935. p. 520. 
The coefficient of trangmissibility was calculated to be 57.9 gallons per day per foot. The trangmissibility is 10w, indicating that the aquifex could be overdeveloped easily. The specific capacity of the well was obtained by dividing the average discharge by the total drawdown, and. found to be 0.185 gallons per minute per foot of dravdown. This means that, wh th a discharge of 21 gallons per miaute, the drawdown would be about 115 feet. With this drawdown, the punging level would be about 240 feet below the 1 and surface.

The data collected during the punping test indicated that, al though the well would produce the desired 21 gallons per minute, the quality of the water was not sat1sfactory for domestie use. Aecordingly, a further short field study was made to determine whether or not the shallower aquifers would produce sufficient water of suitable quality to supplement the existing supply. Records of the wells and springs visited are given In table 1.

\section{QUATIIT OF WATER}

Analyses of water samples from nine wells in the vicinity of thoreau are shovn in table 3 .

The Santa Pe Rallroad vells at Chavez are reported to produce water from the San Andres formation. As show by the analysis for well 17 , water fron this aquifer is hard. If no other water of better quality were available, water from the San Andres formation in the vicinity of Chavez probably would be satisfaetory for most domestic purposes.

Nater encountered in the Chinle formation varies in quality both with depth in fomation and fron place to place in the Thoreau area. Nater from 
the upper part of the formation contains a noderate concentration of dissolved solids at Thoreau and would be satisfactory for domestic use, as shown by the analyses for weIls 21 and 22. These wells are located less than a mile from the school.

Apparently water from the middie sandstone member of the Cinlnie formation is rather highly mineraliged at Thorean, as show by the analyses for the school weil (No. 19). which is reyorted to develop vater from this part of the fomation. The vell was sampled three times during the pumping test on Argugt 18 and 19. Although the gamples show some variation in chemieal charactor as pumping proceeded, it appears unlikely that contimed pumping would materlally Improve the quality of the water. The analyses show that the water from this well is comparatively soft, but the water contains excessive concentrations of sodiun, chloride, and sulfate, and therefore is considered unsatisfactory for domestic use. Hater of loter dissolved solids content from the middle sandstone member of the Ginle fornation contains mostly sodium and biearbonate, as shown by the analyses for wells 9 and 20 . although the proportion of sulfate to total dissolved solids is nearly as great as in the more highly mineralized water.

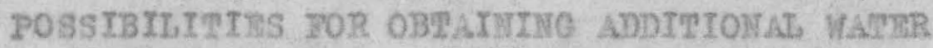

The records of valls 2 and 22 show that wells near the school prodace at 1 east 4 gallons per mimte from a clepth of about 200 to 250 feet. Table 3 Indicates that the water from vells 21 and 22 is of better quality than the water from well 19.

Tho methods by which additional water of better quallty could be obtained. at the thoreau school are: (1) Perforate the casing of well 19 from 200 to 250 feet, allowing water fron the shallower aquifers to enter the well:

(2) drill a well near the school to a depth of about 250 feet, and mix the 
water produced from the new well whth water produced from vell 19. The water from vell 19 should be diluted with at least twice as much water froa the shallower aquifers.

The investigation showed that the Glorlete sandstone nember of the Sen Ancres formation may bo water bearing at the Thoreen school. The waterbearing character of the sandstone and the quality of water that might be yielded could be detemined by arilling a test well. The torg of the sandstone is estimated to be about 850 feet below the land surface at Thorean. coverUSYONS AND RECOMMRNDATON'S

1. A ninimum of 21 gallons per mimte of potable water will be needed at the Thoreau Indian school as soon as the sehool is opened.

2. The existing well at the school will produce 21 gallons per mimute, but the water is of poor qual 1ty.

3. Additional vater could be obtained by: (1) Perforating the casing in the school well between 200 and 250 feet, allowing water of better quallty to enter the vell: (2) drilling a nov well near the school to a depth of about 250 feet.

4. If no more than 21 gallons per mimute is avallable for the school, the pumpling plant would have to be operated 16 hours per day. If both the alternatives outlined in paregraph 3 of this section are folloned, the pumping plant covid be operated a shorter perlod each day and a standby supply woulo be available in the event of temporary fallure of one of the vells.

5. If the school is expanded at a later fate and mose water is needed, the Clorieta sandstone namber of the San Andres fomation may yield sufficient water of suitable quality to aupply the increased requirements, although the water may be hard. 


\begin{tabular}{|c|c|c|c|c|c|c|c|}
\hline $\begin{array}{l}\text { Office } \\
\text { Number }\end{array}$ & $\begin{array}{l}\text { Location } \\
\text { and } \\
\text { State file number }\end{array}$ & OMmer & Dri116r & $\begin{array}{l}\text { Date } \\
\text { com- } \\
\text { ple- } \\
\text { ted }\end{array}$ & $\begin{array}{c}\text { Altitude } \\
\text { above } \\
\text { sea level } \\
\text { (feet) }\end{array}$ & $\begin{array}{l}\text { Pepth } \\
\text { of } \\
\text { well } \\
\text { (feet) }\end{array}$ & $\begin{array}{c}\text { Diam- } \\
\text { eter } \\
\text { of } \\
\text { well } \\
\text { (in.) }\end{array}$ \\
\hline d 9 & 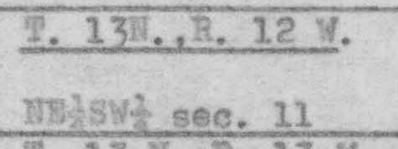 & Nevajo Service & c.c.c. & 19348 & $=$ & 1,987 & 7 \\
\hline d 15 & 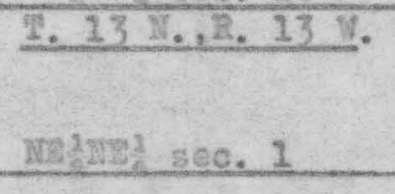 & A.2.8. S.F. Bralroad. & Iyman of Glampitit & 1902 & - & 707 & 10 \\
\hline 16 & do. & do. & Gus Moulnolland & 1911 & $=$ & 725 & 10 \\
\hline d/ 17 & 6. & do. & Clannitt \& Noss & 1928 & - & 930 & $12^{3}$ \\
\hline d) 19 & 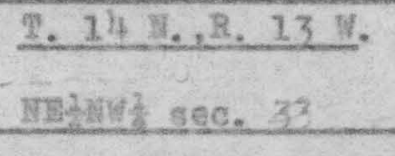 & Navajo Service & c.c.c. & $1934 ?$ & 7.163 & 505 & 10 \\
\hline$d / 20$ & mutwit sec. 28 & do. & Kiersey and Co. & 1932 & - & 730 & $10 \frac{1}{2}$ \\
\hline$d / 21$ & St:igry sec. 33 & J. J. Radosevich & Oscar Carter & $=$ & 7,355 & 235 & 6 \\
\hline di2? & do. & Oscax Carter & do. & - & 7.160 & 227 & $5^{3}$ \\
\hline$d 23$ & 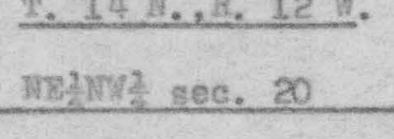 & Ilavaio Service & Thos. Sartin & 1942 & - & 430 & 8 \\
\hline$d / 24$ & swaste sec. 17 & do. & - & - & - & - & $=$ \\
\hline
\end{tabular}




\begin{tabular}{|c|c|c|c|c|c|c|}
\hline $\begin{array}{l}\text { Office } \\
\text { number }\end{array}$ & & $\begin{array}{l}\text { level } \\
\text { Date of } \\
\text { measure- } \\
\text { ment, } \\
\text { int } 1948 \\
\text { a/ }\end{array}$ & $\begin{array}{l}\text { Pump } \\
\text { and. } \\
\text { power } \\
\text { b/ }\end{array}$ & $\begin{array}{l}\text { Use } \\
\text { of } \\
\text { vater } \\
\text { ef }\end{array}$ & $\begin{array}{l}\text { Temp. } \\
\mathrm{O}_{\mathrm{F}}\end{array}$ & Remarks \\
\hline 9 & 80.65 & June 25 & C.G & $D$ & 56 & $\begin{array}{l}\text { Baca sehool. Plugged back to } 475 \text { feet to eut off "bad" water. } \\
\text { Reported discharge, } 4 \text { ? gallons per mimute from Chinle formation. See 10\%. }\end{array}$ \\
\hline 15 & Mows & - & $A, D$ & $R R$ & 62 & $\begin{array}{l}\text { At Chavez. Measured flow, } 3 \text { gallons per minute, June } 25,1948 \text {. Reported } \\
\text { discharge by air } 11 f t, 100 \text { gallons per mimte. Reported to produce vater } \\
\text { from alorieta sandstone member of San Andres. fornation. See log. }\end{array}$ \\
\hline 16 & 10 & el & $A, D$ & $\mathrm{RR}$ & - & $\begin{array}{l}\text { At Chavez. Reported to have flowed } 13 \text { gallons per mimte in } 1911 . \\
\text { See log. }\end{array}$ \\
\hline 17 & Mlows & - & A, D & $\mathrm{RR}$ & 65 & $\begin{array}{l}\text { Heasured discharge, } 20 \text { gallons per ininute, June } 25,1948 \text {. Peported to } \\
\text { have floved } 5 \text { gallons per mimute in } 1918 \text {. See } 105 \text {. }\end{array}$ \\
\hline 19 & 1.21 .98 & July 30 & Mone & II & 56 & $\begin{array}{l}\text { Thorean school. Had been sealed for several years prior to measurement. } \\
\text { Test pumped by aix lift, ang. } 17-19,1948 \text {. Produces water from chinle } \\
\text { fomation. Su log. }\end{array}$ \\
\hline 20 & 280 & el. & C, $\mathbb{E}$ & $s$ & - & $\begin{array}{l}\text { Reported drawdom, } 160 \text { feet after pumping } 18 \text { gallops per mimto for } 1 / 2 \\
\text { hour. Produces vater from Ohinle formation, See } \log \text {. }\end{array}$ \\
\hline 21 & 60 & el & C. & $D$ & - & $\begin{array}{l}\text { Reported discharge, } 8 \text { gallons per minute. Produces water from Chinle } \\
\text { formation. }\end{array}$ \\
\hline 22 & 60 & $\mathrm{e} /$ & C, V & D & - & $\begin{array}{l}\text { Reported discharge, } 4 \text { gallons per minute. } \\
\text { Produces vater from Chinle formation. }\end{array}$ \\
\hline 23 & 95 & el & c. 12 & D, S & - & $\begin{array}{l}\text { At San Antonio sheep station. Produces water from ChInle formation. } \\
\text { See loe. }\end{array}$ \\
\hline 24 & - & - & - & 8 & 45 & Soring. \\
\hline
\end{tabular}


Table 2. - Logs of wells in Thoreau area, Mokinley County, Hew Mexico.

Formations Identified by H. A. Whitcomb and I. C. Halpenny

\begin{tabular}{ll}
$\begin{array}{l}\text { Whick - } \\
\text { ness } \\
(\text { feet })(\text { feet })\end{array}$ & $\begin{array}{l}\text { Thick- } \\
\text { neas } \\
\text { (feet) }\end{array}$ \\
\hline
\end{tabular}

Drillerts log of weil 9.

Nevejo Service, owner.

Bace Indian school.

Surface sand

Chinze fornation

Ward send

lurple shale

Derk-eray sand

Dark-blue shele

Gray shale

Rea shale

PL Lhale

Gray lime

Purple shole

Gray 11 sie

Green shele

Derk-gray water sand ( 5 epm)

Sandy exey shale

Gray and

Sondy gray shele

Qrey sand

Gray shale

Red shale

Gray shrie

Plirple shale

Red shole

Brown shale

Qx shele

Z1. shell

Red shale and herd conglowerats

Sandy Mine

Gray Band

Sand, little water

Red shale

Bed shale with line shell

Gray shale

Herd gray sand

Oray IIne shell

Oroy lime

Sand, 11 ttle water

sandy brown ghale

fred shale.

Shinarump conelomerate (?)
Dr111er's log of well 9 , cont. Sen Andres fornation

$\frac{\text { Sen Andres 2imestone member }}{\text { Gray lime }} \quad 46$

Qlerieta asdatone nember

White water sand

Heurd whits sand

Hard Bray send

White sand

Gray shale

thit te gand

Yeeo formst10n (i)

Grey shale

Red send

Red sand with shale streaks

Sandy red ghale

Red sand

Bed shole

Red, water atad, ( $37 \mathrm{gpm})$

Hed shaze

Sti cky red clay

Red shade

Sandy red shale

Intwe shell

Gray send

Dark-gray 11 we

BIue shele

Gray send

saudy gray shale

Oray sand

Sandy red ghele

Hed sandetone

Dark-eray line

Bendy red ghrie

Daxk-Gray 11 wee

Sandy red ehale

Dari-gray line

sandy red shale

Red shale

sandy red shale

Red water wand

Red sand

Abo formation (?)

13 617 \$andy red shale
663

673

676

684

796

799

851

52

3

22

37

27

24

12

7

6

6

17

49

5

12

22

2

2.2

3

14

14

2

5

38

2

66

6

254

18

48

854

866

883

900

914

926

933

939

945

962

1.012

1,016

2,022

1,034

1.036

1,040

2,051

3,054

2,058

2,072

1,074

2.079

1.,084

1,222

1,124

1,390

1,196

1,450

2,468

2.516

24 $\quad 2.540$ 
Table 2. - Logs of wells in Thoreau area, Hekiniey County, Hew Hexico - Cont.

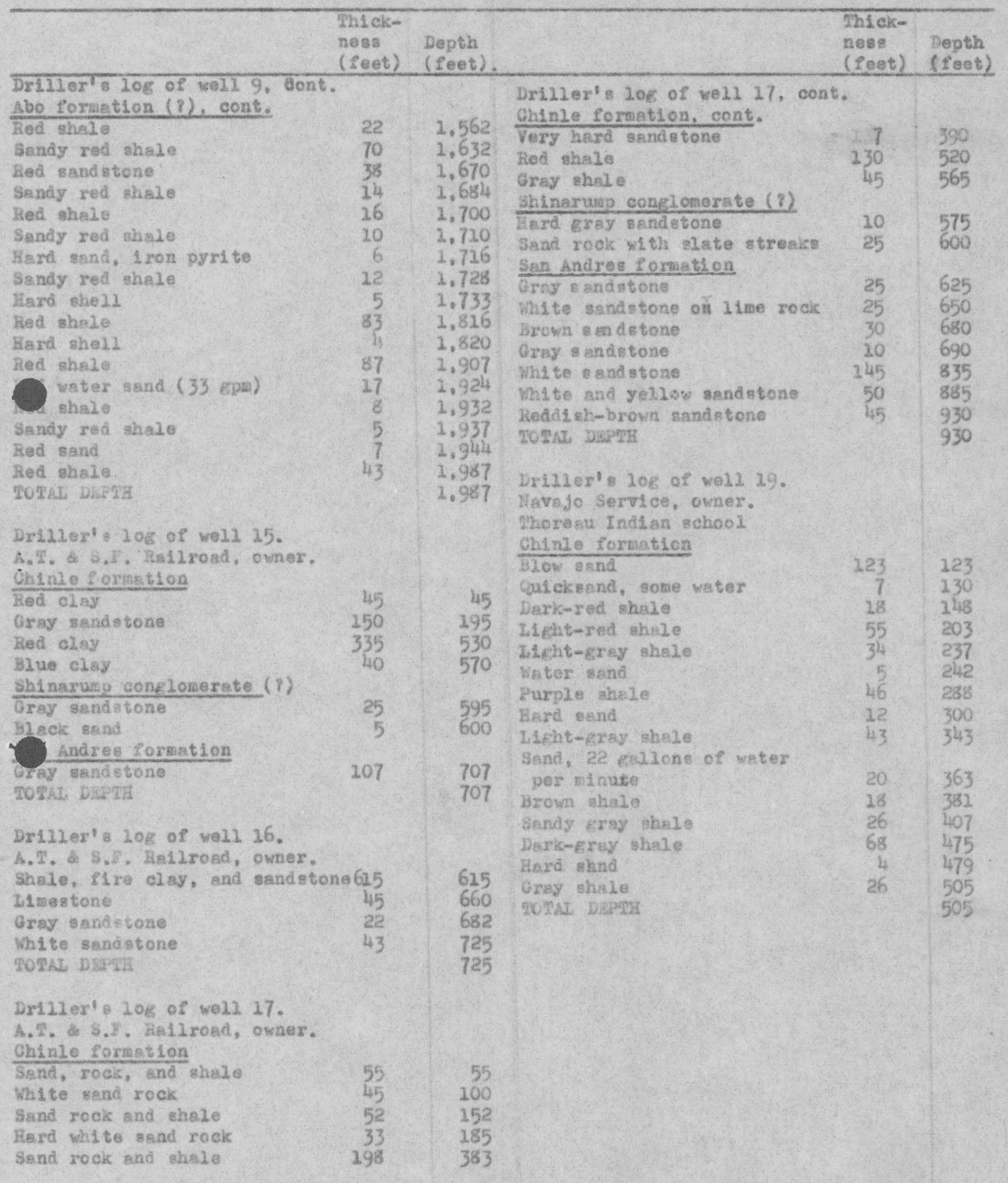


mable 2. - Logs of welle in thoreeu srea, Mekinley County, Hev Mexico - Cont.

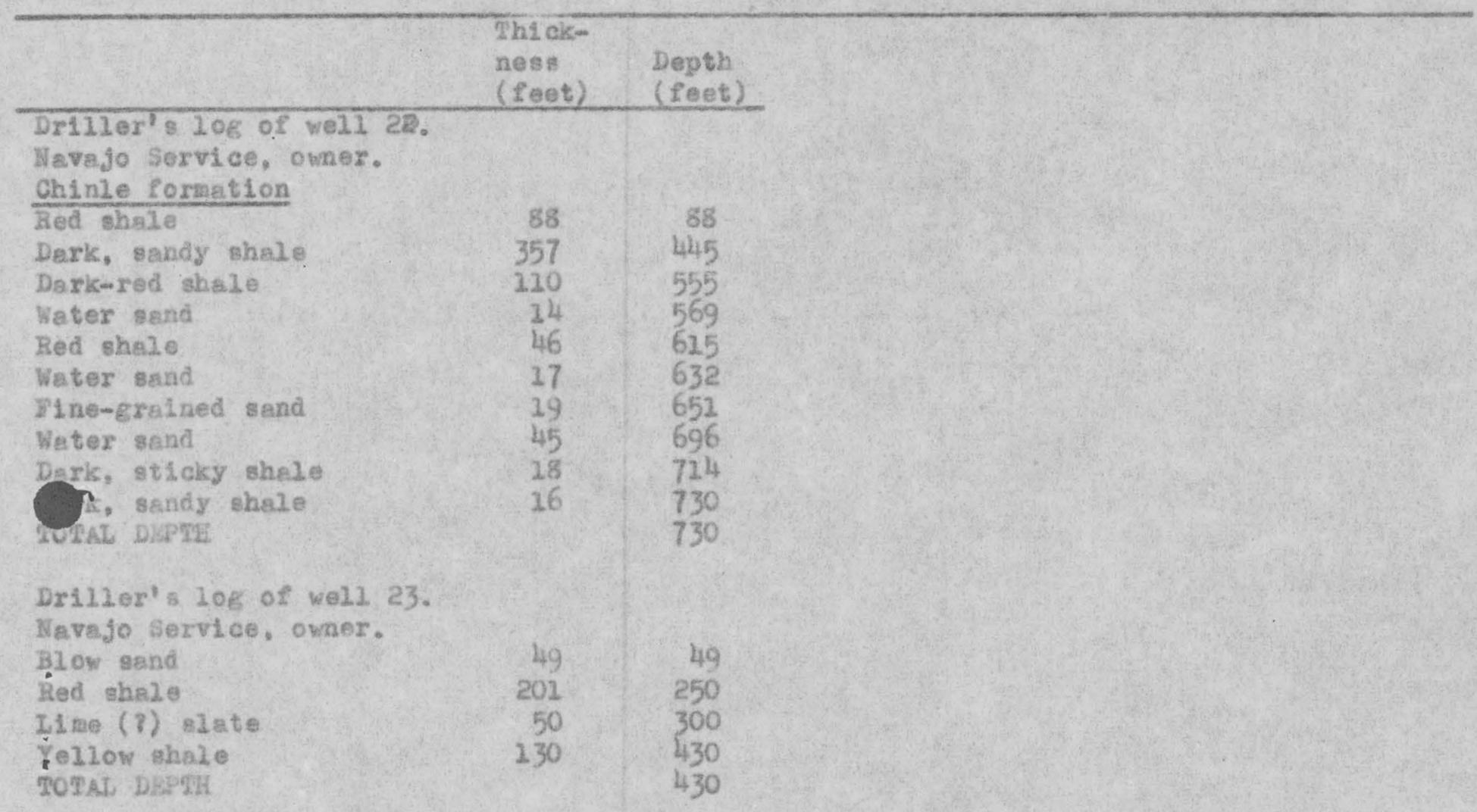


Table 3. - Anglyses of water from wells and springs in Thoreau area, McKinley County, New Mexico. Analyzed in Southwestern Laboratory of Geologicel Survey, Albuquerque, New Nexico.

(Numbers correspond to numbers given in table 1 and plate 1.)

(Parts per million except specific conductance.)

\begin{tabular}{|c|c|c|c|c|c|c|c|c|c|c|c|c|}
\hline No. & $\begin{array}{c}\text { Date of } \\
\text { collection } \\
1948\end{array}$ & $\begin{array}{l}\text { Specific } \\
\text { conductance, } \\
\text { (micromhos } \\
25^{\circ} \mathrm{c} . \text { ) }\end{array}$ & $\begin{array}{l}\text { Cal- } \\
\text { cium } \\
\left(\mathrm{Ca}_{2}\right)\end{array}$ & $\begin{array}{l}\text { Mag- } \\
\text { nesiun } \\
\text { (Mg) }\end{array}$ & $\begin{array}{l}\text { Sodium } \\
\text { and } \\
\text { Potassium } \\
\text { (Nafk) }\end{array}$ & $\begin{array}{l}\text { Bicar- } \\
\text { bonate } \\
\left(\mathrm{HCO}_{3}\right)\end{array}$ & $\begin{array}{l}\mathrm{Sul-} \\
\text { fate } \\
\left(\mathrm{SO}_{4}\right)\end{array}$ & $\begin{array}{l}\text { Ghic- } \\
\text { ride } \\
\text { (ci) }\end{array}$ & $\begin{array}{l}\text { Iuluo- } \\
\text { ride } \\
(\mathrm{P})\end{array}$ & $\begin{array}{l}\mathrm{NI-} \\
\text { trate } \\
\left(\mathrm{NO}_{3}\right)\end{array}$ & $\begin{array}{l}\text { Dis- } \\
\text { golved } \\
\text { solids }\end{array}$ & $\begin{array}{l}\text { Total } \\
\text { hard- } \\
\text { ness } \\
\text { as } \\
\mathrm{CaCO}_{3}\end{array}$ \\
\hline 9 & June 23 & 727 & 45 & 37 & 104 & 332 & 1.02 & 15 & 3.5 & 0.5 & 462 & 182 \\
\hline 15 & June 25 & 762 & - & - & - & 272 & - & 5 & - & - & - & \\
\hline 17 & do. & 889 & 125 & 37 & 23 & 256 & 285 & 5 & 0.2 & 0.6 & 615 & 464 \\
\hline a/ 19 & Aug. 18 & 3.590 & 26 & 10 & 760 & 272 & 515 & 705 & 1.0 & 4.5 & 2,160 & 106 \\
\hline$\frac{b}{19}$ & do. & 3.700 & - & - & - & 259 & - & 725 & - & - & - & $=$ \\
\hline s/ 19 & Aug. 19 & 3,630 & 18 & 3.8 & 867 & 260 & 534 & 705 & 1.0 & 2.4 & 2.260 & 60 \\
\hline 20 & Dec. 3 & 576 & 1.2 & .5 & 142 & 276 & $5^{4}$ & 19 & .4 & .9 & 353 & 5.0 \\
\hline 21 & Dec. 6 & 679 & 52 & 11 & 85 & 289 & 64 & 34 & .2 & 9.3 & 398 & 174 \\
\hline 22 & do. & 1.090 & 26 & 7.0 & 217 & 334 & 184 & 50 & .5 & 10 & 672 & 94 \\
\hline 23 & Mov. 25 & 4.380 & 7.0 & 11 & 911 & 502 & 523 & 765 & 2.6 & 2.5 & 2.470 & 62 \\
\hline 24 & do. & 881 & 2.0 & 3.3 & 219 & 436 & 77 & 33 & 2.2 & 8.6 & 552 & 18 \\
\hline
\end{tabular}

Q/ Collected at $11: 38$ a.m.

b/ Collected at $1: 13 \mathrm{p} . \mathrm{m}$.

c) Collected at 1:00 p.m. 